\title{
CEPAEA NEMORALIS ON THE EAST SUSSEX SOUTH DOWNS, AND THE NATURE OF AREA EFFECTS
}

\author{
RICHARD W. ARNOLD* \\ Department of Zoology, Oxford
}

Received 28.v.70

\section{IntRoduction}

ON high open downland in England, populations of the polymorphic landsnail Cepaea nemoralis tend not to vary with habitat, despite predation by at least one predator known to exert strong visual selection, the Song Thrush (Turdus ericetorum Turton). Morph frequencies remain relatively constant over areas of downland very much larger than the panmictic area of populations of the species, and then change over long or short distances equally without reference to the nature of the background of the habitat (Cain and Currey, 1963a, $b$; Carter, 1968a). Cain and Currey (1963a) called these phenomena area effects, and suggested that the factors causing them override the effects of visual selection by predators. The latter form of selection almost certainly is the cause of populations resembling their backgrounds in the English lowland and wooded chalk hill regions investigated (Cain and Sheppard, 1954; Currey, Arnold and Carter, 1964; Arnold, 1966).

Cain and Currey (1963a) concluded that selection is responsible for causing area effects for they cover huge areas and the populations are large. They suggested (1963b) that if a sufficient number of area effects could be studied the nature of the non-visual, possibly climatic, selective agents causing different area effects might be elucidated.

The results of a survey of populations on the eastern South Downs, chosen because the region is one of the sunniest in Britain, are described in this paper.

\section{The REgion AND ITS habitats}

The eastern 20-miles $(32 \mathrm{~km}$.) of the South Downs (between Brighton and Eastbourne) rise very steeply from the Greensand plain to the north to an escarpment height of between 500 and 800 feet (165 and $265 \mathrm{~m}$.). The plateau slopes from the escarpment towards the sea for a distance of between 4 and 6 miles (6 and $10 \mathrm{~km}$.) (fig. 1). The eastern limit of the Downs is at Eastbourne. The Rivers Ouse and Cuckmere divide the Downs between Lewes and Newhaven, and between Alfriston and Guckmere Haven respectively, and the region collected over can conveniently be considered as three districts: a western district, extending from just north-west of Brighton (at which sampling of populations was arbitrarily stopped) to an eastern limit at the River Ouse; a central district, between the two rivers; and an eastern district bounded in the west by the River Cuckmere and reaching to the eastern limit of the Downs by Eastbourne.

All the districts are open, and woodland is rare. There are a few small mixed deciduous woods, mainly of Ash (Fraxinus excelsior L.), Sycamore (Acer pseudoplatanus L.), and Beech (Fagus sylvatica L.), in the central and eastern districts. The only large wood, Friston Forest in the eastern district,

* Present address: Department of Zoology, University College of North Wales, Bangor. 


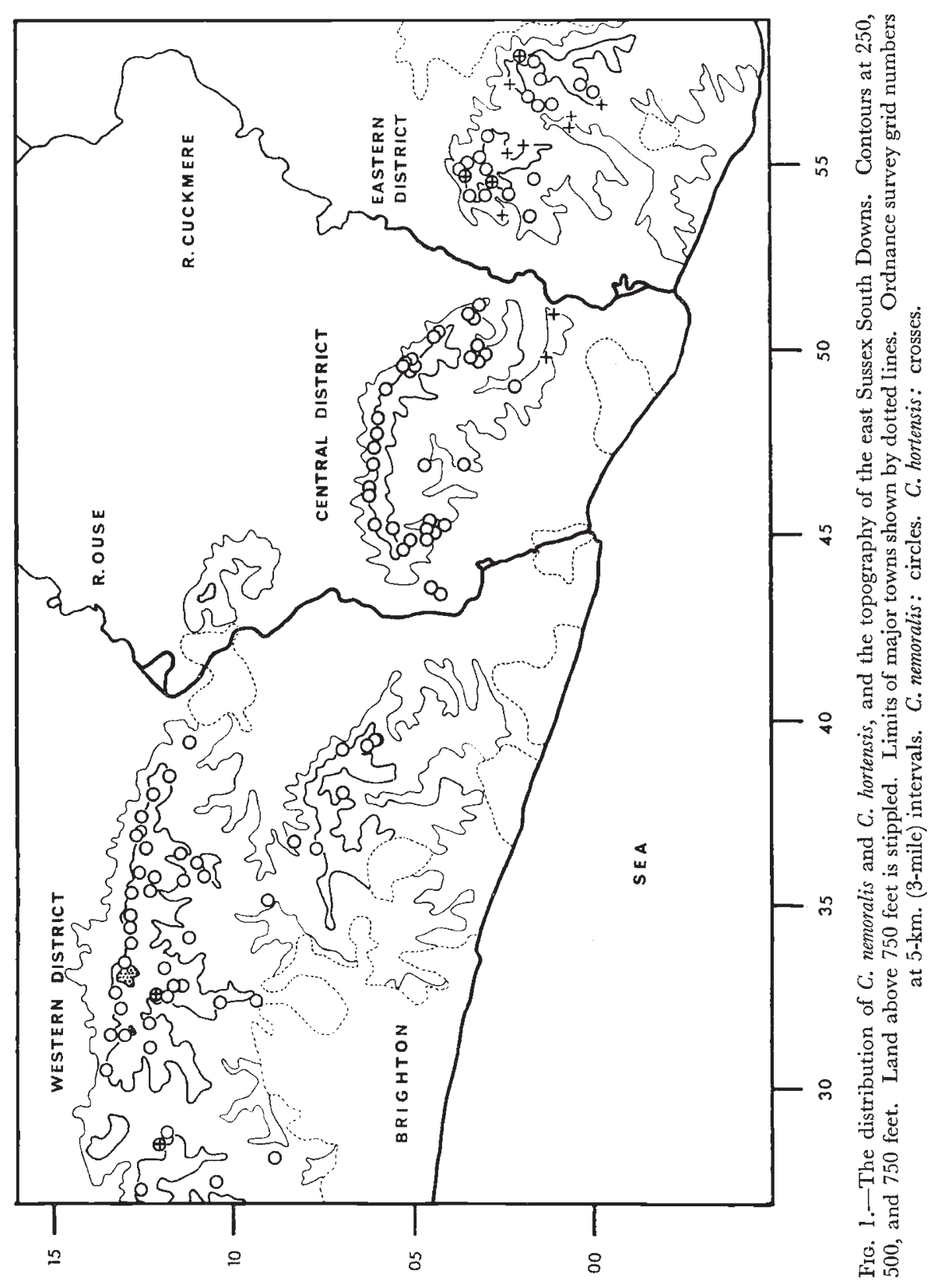


is coniferous, and Cepaea was not found there. The western district is more wooded, with several Beech plantations on the plateau and a few small woods on the escarpment. Most of the land on the plateau is ploughed up for cereal cultivation, restricting severely the present distribution of Cepaea there. The escarpment on the other hand has extensive swards of grazed grassland in which the larger grasses form associations. Of especial importance in the flora of the escarpment are Helictotrichon pratense L., Zerna erecta Huds., and Brachypodium pinnatum L.

In comparison with other downland regions on which Cepaea populations have been described, Gorse (Ulex europaeus L.) is widespread and abundant, particularly on the plateau, and large expanses of dense gorse are found on uncultivated areas. Blackthorn (Prunus spinosa L.) is locally abundant, and it is also particularly frequent on the plateau. C. nemoralis was often found in gorse and blackthorn scrub (in some places such habitats were the ones in which the species was most likely to be encountered), and I have classed as "scrub" any habitats in which there was more than 50 per cent. cover from low woody vegetation. Scrub probably resembles the "mixed" class of Cain and Currey (1963a). In some scrub habitats, backgrounds ranged from brownish without much grass to being predominantly grassy. All however were browner than grass habitats.

A higher proportion of scrub samples was taken in the east of the region. Fourteen out of 19 in the eastern district were scrub samples, compared with 13 in 35 in the central district, and 13 in 45 in the western district. These figures probably reflect moderately accurately the actual proportions of scrub compared with other habitats in the three districts.

There is no reason to believe that the other habitat types on the South Downs differed much in visual characteristics from the same habitat types sampled in earlier surveys elsewhere.

\section{Methods}

Between February 1962 and July 1964, samples were made wherever Cepaea could be found. Difficulty was frequently experienced in finding sufficient shells to compose the samples, and nine small samples (containing less than twenty but more than seven shells) are included in the analysis. Attention was concentrated on the escarpment, for $C$. nemoralis was often common there and a greater coverage of surveyed country was thereby made possible. Eight samples were taken from deciduous woods in the region.

The samples were scored for age, condition, and colour and banding, following the methods of Cain and Sheppard (1950, 1954). Only adult shells were used in calculating morph frequencies. The gene notation and morph nomenclature used are Cain, Sheppard and King's (1968). Details of the samples are given in the tables.

\section{(i) The distribution of species}

\section{REsults}

Localities in which the species C. nemoralis and Cepaea hortensis Müll. were recorded are shown in fig. 1. C. nemoralis was encountered most regularly on the escarpment of the Downs, especially on that of the western district where it was often abundant. It was generally difficult to find on the plateau, and it seemed to be absent from many apparently suitable habitats there, 
TABLE 1

Samples of C. nemoralis from the Western District

\begin{tabular}{|c|c|c|c|c|c|c|c|c|c|c|}
\hline \multirow[b]{2}{*}{$\begin{array}{l}\text { Map } \\
\text { eference }\end{array}$} & \multicolumn{4}{|c|}{ Yellow } & \multicolumn{4}{|c|}{ Pink } & \multirow[b]{2}{*}{ Total } & \multirow[b]{2}{*}{$\begin{array}{l}\text { Habitat } \\
\text { and notes }\end{array}$} \\
\hline & " $0 "$ & " 3 " & $" 5 "$ & Tri & $" 0 "$ & $" 3 "$ & " $5 "$ & $\widetilde{\text { Tri }}$ & & \\
\hline 272126 & - & - & I & - & - & - & 14 & - & 15 & G \\
\hline 275107 & - & 2 & 20 & 2 & - & - & - & - & 24 & $\mathrm{G} * *$ \\
\hline 281089 & - & 5 & 16 & - & - & 2 & 2 & 1 & 26 & $\mathrm{~S}$ \\
\hline 288119 & - & 4 & 15 & 2 & - & - & - & 一 & 21 & $\mathrm{H}$ \\
\hline 306137 & - & 2 & 27 & 3 & 11 & - & 1 & - & 44 & $\mathrm{G}$ \\
\hline 310123 & 8 & 5 & 17 & - & - & - & - & - & 30 & $\mathrm{H}$ \\
\hline 313130 & 5 & - & 22 & - & 2 & - & 4 & - & 33 & G \\
\hline 314135 & 15 & - & 5 & 一 & 1 & - & - & - & 21 & $\mathrm{~S}$ \\
\hline 318124 & - & 4 & 33 & - & - & - & - & - & 37 & $G$ \\
\hline 322104 & 15 & - & 14 & - & - & - & - & - & 29 & $\mathrm{H}$ \\
\hline 322123 & 6 & 1 & 39 & - & - & 一 & - & - & 46 & $\mathrm{G}$ \\
\hline 323122 & 3 & 2 & 23 & - & - & - & 1 & - & 29 & $\mathrm{G}^{*}$ \\
\hline 323095 & 7 & 3 & 13 & - & 4 & - & - & - & 27 & $\mathrm{~S}$ \\
\hline 325119 & II & 3 & 46 & - & - & - & 1 & - & 61 & $G(2)$ \\
\hline 325134 & 一 & - & 29 & - & - & - & - & - & 29 & $\mathrm{G}$ \\
\hline 327118 & 5 & 1 & 42 & - & - & - & 4 & - & 53 & $\operatorname{MDW}(2) \dagger$ \\
\hline 327115 & 4 & 7 & 2 & - & 2 & 3 & 4 & 1 & 25 & MDW $(1) \dagger$ \\
\hline 331120 & - & - & 22 & - & - & - & - & - & 22 & $\mathrm{H}(\mathrm{I})$ \\
\hline 333130 & - & - & 79 & - & - & - & - & - & 79 & $\mathrm{G}$ \\
\hline 339129 & - & 4 & 18 & - & - & - & - & - & 22 & G \\
\hline 342113 & 一 & 1 & 30 & - & - & - & 1 & - & 32 & $\mathrm{~S}$ \\
\hline 343130 & - & 3 & 50 & 1 & - & - & - & - & 54 & G \\
\hline 347130 & - & 4 & 20 & - & - & 一 & - & 一 & 24 & G \\
\hline 353128 & - & 10 & 56 & 2 & - & - & 1 & - & 69 & G \\
\hline 353124 & 一 & 13 & 40 & - & - & 2 & 4 & 1 & 60 & $\mathrm{~S}$ \\
\hline 356114 & - & - & 16 & - & - & 5 & 17 & - & 38 & MDW (3) \\
\hline 358108 & - & 7 & 72 & - & - & - & - & - & 79 & $\mathrm{G}(3)$ \\
\hline 358122 & - & 25 & 81 & - & - & - & - & - & 106 & $\mathrm{~s}$ \\
\hline 359127 & - & 5 & 22 & - & - & I & I & - & 29 & $\mathrm{G}(4)$ \\
\hline 362111 & - & 6 & 51 & 1 & - & - & - & - & 58 & $\mathrm{G}$ \\
\hline 363115 & - & 2 & 42 & - & - & - & 1 & - & 45 & $\mathrm{~s}$ \\
\hline 366078 & - & 5 & 9 & - & - & - & - & - & 14 & $\mathrm{G}$ \\
\hline 367084 & 3 & - & 35 & 2 & 2 & - & 12 & - & 54 & St+† \\
\hline 368124 & - & 5 & 36 & 1 & - & 5 & 42 & - & 89 & $\mathrm{BW}(4)$ \\
\hline 370127 & - & 14 & 23 & 1 & - & - & 4 & - & 42 & $\operatorname{MDW}(5)$ \\
\hline 371126 & - & 24 & 37 & 1 & - & - & 4 & - & 66 & $G(5)$ \\
\hline 375126 & - & 1 & 63 & - & - & - & - & - & 64 & $\operatorname{MDW}(6)$ \\
\hline 380123 & - & 5 & 90 & - & - & - & 3 & - & 98 & $\mathrm{RH}(6)$ \\
\hline 380070 & - & 4 & 5 & 1 & - & 4 & 1 & - & 15 & $\mathrm{~S}$ \\
\hline 386119 & - & 10 & 75 & - & - & 4 & 7 & - & 96 & RH \\
\hline 393064 & 6 & 8 & 28 & - & - & - & - & - & 42 & $\mathrm{~S}$ \\
\hline 394113 & 3 & - & 13 & - & 3 & - & 19 & - & 38 & RH \\
\hline 395062 & 2 & 44 & 71 & 5 & - & - & - & - & 122 & $\mathrm{~S}$ \\
\hline 395061 & I & 30 & 79 & 2 & - & - & - & - & 112 & $\mathrm{~S}$ \\
\hline 392069 & 3 & 1 & 7 & 1 & 4 & 1 & 14 & - & 31 & S \\
\hline 285121 & - & - & 2 & - & - & - & - & 一 & 2 & S* \\
\hline 351091 & - & - & - & - & - & - & - & - & 1 & $\mathrm{H} \uparrow$ \\
\hline
\end{tabular}

Notes: † Plus one Brown " 0 ", included in the total.

$\dagger$ Plus two Brown " 0 ", included in the total.

$\dagger \uparrow \uparrow$ Yellow " 5 " coloumn includes one Yellow " 5 " hyal. 


\section{Explanation of tables $1-4$}

1. Map reference from the Ordnance Survey national grid square TQ.

2. " 0 ", " 3 ", " 5 ": phenotypes of band formulae 00000,00300 , and 12345 (with minor variants) respectively. Tri: trifasciata, 00345 . Hyal: hyalozonate.

3. Rare morphs in samples are described in footnotes.

4. Habitats: $\mathrm{RH}=$ Rough herbage, $\mathrm{H}=$ Hedgerow. $\mathrm{G}=$ Grass. $\mathrm{S}=$ Scrub. MDW $=$ Mixed deciduous wood. $\mathrm{BW}=$ Beechwood.

5. Wood-Open-habitat pairs, explained in the text, are shown by numbers in the habitat column. Each member of a pair has the same number.

6. Presence of $C$. hortensis $(*)$ and Cochlicella acuta $(* *)$ is noted in the final column.

7. Samples containing less than eight $C$. nemoralis are shown in fig. 1 only, and are omitted from the morph frequency diagrams.

TABLE 2

Samples of C. nemoralis from the Central District

\begin{tabular}{|c|c|c|c|c|c|c|c|c|c|c|}
\hline \multirow[b]{2}{*}{$\begin{array}{l}\text { Map } \\
\text { reference }\end{array}$} & \multicolumn{4}{|c|}{ Yellow } & \multicolumn{4}{|c|}{ Pink } & \multirow[b]{2}{*}{ Total } & \multirow[b]{2}{*}{ Habitat } \\
\hline & "0" & "3" & " $5 "$ & Tri & " 0 " & "3" & " $5 "$ & Tri & & \\
\hline 433043 & 24 & 15 & 35 & - & - & - & 8 & - & 82 & $\mathrm{~S}$ \\
\hline 434045 & 18 & 44 & 30 & - & 13 & 42 & 26 & - & 173 & G \\
\hline 447053 & 一 & 25 & 5 & - & - & 4 & 1 & - & 35 & $\mathrm{~S}$ \\
\hline 449047 & - & 12 & 9 & - & - & 2 & 2 & - & 25 & G \\
\hline 449052 & - & 33 & 12 & - & - & 13 & 4 & - & 62 & $\mathrm{~S}$ \\
\hline 451045 & - & 13 & 11 & 1 & - & 5 & 3 & - & 33 & G \\
\hline 452046 & - & 10 & 19 & - & - & 5 & 10 & - & 44 & G \\
\hline 452042 & 5 & 3 & 13 & - & - & 9 & 25 & - & 55 & $\mathrm{~S}$ \\
\hline 452060 & - & 一 & 5 & - & 一 & - & 28 & - & 33 & S \\
\hline 453057 & - & 9 & 5 & - & - & 7 & 1 & - & 22 & $\mathrm{~S}$ \\
\hline 454045 & - & 18 & 22 & 1 & - & 4 & 14 & - & 59 & $\mathrm{~S}$ \\
\hline 461063 & - & - & 15 & - & - & 1 & 8 & - & 24 & G \\
\hline 463062 & - & 7 & 63 & - & - & 3 & 33 & - & 106 & G \\
\hline 469036 & - & - & 4 & - & - & 1 & 36 & - & 41 & $\mathrm{~S}(8)$ \\
\hline 469047 & - & 4 & 4 & - & 一 & 3 & 13 & - & 24 & MDW (8) \\
\hline 469061 & - & - & 7 & - & - & 1 & 14 & - & 22 & G \\
\hline 473062 & - & - & - & - & - & 28 & 27 & - & 55 & $\operatorname{MDW}(7)$ \\
\hline 478061 & - & 1 & 10 & - & - & 5 & 44 & - & 60 & $G(7)$ \\
\hline 481061 & - & 5 & 20 & - & - & 2 & 21 & - & 48 & $\mathrm{G}$ \\
\hline 489059 & - & - & 5 & - & - & 3 & 39 & - & 47 & G \\
\hline 491021 & - & - & 1 & - & - & - & 7 & - & 8 & $\mathrm{~S}$ \\
\hline 493053 & - & - & 3 & - & - & - & 16 & - & 19 & G \\
\hline 494052 & - & - & 7 & - & - & - & 33 & - & 40 & RH \\
\hline 495053 & - & - & 14 & - & - & - & 27 & - & 41 & G \\
\hline 496052 & - & - & 6 & - & - & - & 15 & - & 21 & G \\
\hline 496053 & - & - & 14 & - & - & - & 13 & - & 27 & G \\
\hline 499029 & - & - & 13 & - & - & - & 24 & - & 37 & G \\
\hline 497032 & - & - & - & - & - & - & 16 & - & 16 & $\mathrm{~S}$ \\
\hline 498034 & - & - & 8 & - & - & - & 53 & 1 & 62 & $\mathrm{~S}$ \\
\hline 502032 & - & - & 2 & - & - & - & 14 & 1 & 17 & G \\
\hline 504045 & - & - & 3 & - & - & - & 20 & - & 23 & G \\
\hline 505044 & - & - & 4 & - & - & - & 44 & - & 48 & G \\
\hline 509034 & - & - & - & - & - & - & 79 & - & 79 & $\mathrm{~S}$ \\
\hline 510035 & - & - & 8 & - & - & - & 51 & - & 59 & $\mathrm{~S}$ \\
\hline 512031 & - & - & - & - & - & - & 14 & - & 14 & $\mathrm{H}$ \\
\hline
\end{tabular}


TABLE 3

Samples of C. nemoralis from the Eastern District

\begin{tabular}{|c|c|c|c|c|c|c|c|c|c|c|c|c|c|c|}
\hline \multirow{3}{*}{$\begin{array}{l}\text { Map } \\
\text { refer- } \\
\text { ence }\end{array}$} & \multicolumn{8}{|c|}{ Yellow } & \multirow{2}{*}{\multicolumn{4}{|c|}{ Pink }} & \multirow[b]{3}{*}{ Total } & \multirow{3}{*}{$\begin{array}{l}\text { Habitat } \\
\text { and notes }\end{array}$} \\
\hline & \multicolumn{2}{|c|}{ " $0 "$} & \multicolumn{2}{|c|}{ " $3 "$} & \multicolumn{2}{|c|}{ “ 5 " } & \multicolumn{2}{|c|}{ Tri } & & & & & & \\
\hline & & Hyal & & Hyal & & Hyal & & Hyal & "0" & "3" & " $5 "$ & Tri & & \\
\hline 537018 & - & - & - & - & 31 & 28 & - & - & - & - & 2 & - & 61 & $\mathrm{~S}$ \\
\hline 542025 & - & - & - & - & 17 & 2 & - & - & - & - & 18 & - & 37 & $S$ \\
\hline 543030 & - & 一 & - & - & - & 110 & - & - & - & - & - & - & 110 & $\mathrm{~S}$ \\
\hline 543035 & - & - & - & - & 18 & 16 & - & - & - & - & 6 & - & 40 & RH \\
\hline 545029 & - & - & - & - & 6 & 25 & - & - & - & - & 3 & - & 34 & $\mathrm{~S}$ \\
\hline 547017 & - & - & - & - & 16 & 2 & 1 & - & - & - & 11 & - & 30 & $\mathrm{~S}$ \\
\hline 547037 & - & - & - & - & 53 & 23 & - & - & - & - & 17 & - & 93 & G* \\
\hline 549030 & - & - & - & - & - & 6 & - & - & - & - & 11 & - & 17 & $\mathrm{~S}$ \\
\hline 549038 & - & - & - & - & 68 & 3 & - & - & - & - & 32 & - & 103 & $\mathrm{~S} \dagger$ \\
\hline 551035 & - & - & - & - & 5 & - & - & - & - & - & 22 & - & 27 & $\mathrm{~S}$ \\
\hline 552032 & - & - & - & - & 17 & 12 & - & - & - & - & 20 & - & 49 & $\mathrm{~S}$ \\
\hline 558029 & - & - & 一 & - & 9 & 1 & - & - & - & - & 16 & - & 26 & $\mathrm{~S}$ \\
\hline 568017 & - & - & 22 & 17 & 2 & l & - & - & - & - & - & - & 42 & $\mathrm{~S}^{* *}$ \\
\hline 570013 & 1 & 1 & 10 & 1 & 18 & 2 & 1 & - & - & 1 & 1 & - & 36 & $H^{*}, * *$ \\
\hline 570000 & 7 & - & 3 & - & 9 & 9 & 19 & - & - & 1 & - & 3 & 51 & $\mathrm{~S}$ \\
\hline 572003 & 15 & 1 & - & - & 23 & 11 & 13 & - & 1 & 一 & - & - & 64 & $\mathrm{H}$ \\
\hline 575015 & - & - & 48 & - & 14 & - & - & - & - & 5 & 6 & 一 & 77 & $\mathrm{~S} \dagger \dagger$ \\
\hline 579017 & 21 & - & 21 & - & 13 & - & - & - & - & - & - & - & 55 & G \\
\hline 581021 & 21 & - & 13 & - & 22 & - & - & - & - & - & - & - & 56 & $\mathrm{~S}^{*}$ \\
\hline 569019 & - & - & - & - & 2 & 1 & - & - & - & - & - & $\ldots$ & 3 & $\mathrm{~S}$ \\
\hline
\end{tabular}

Notes: † Pink " 5 " column includes one Pink " 5 " hyal.

t† Plus four Brown " 0 ", included in the total.

Distinction between five-banded hyalozonate and trifasciata hyalozonate shells is difficult to make, as the upper two bands in five-banded shells are frequently ill-defined, and their presence or absence in hyalozonate shells may not be determined easily. Doubtful cases have been assigned to the five-banded hyalozonate class. This probably accounts for the deficiency of trifasciata hyalozonate shells in samples 570000 and 572003.

It has been assumed that the hyalozonate gene (and not the one for white-lip versus normal pigmentation of lips) is responsible for the white lip of unbanded shells.

TABLE 4

Samples of $\mathrm{C}$. hortensis only from the East Sussex Downs

$\begin{array}{lccc}\text { District } & \begin{array}{c}\text { Map } \\ \text { reference }\end{array} & \begin{array}{c}\text { Size of } \\ \text { sample }\end{array} & \text { Habitat } \\ \text { Central } & 498013 & 63 & \mathrm{~S} \\ & 510012 & 4 & \mathrm{~S} \\ \text { Eastern } & 536025 & 1 & \mathrm{~S} \\ & 553019 & 40 & \text { MDW } \\ & 554023 & 7 & \mathrm{~S} \\ & 561007 & 2 & \mathrm{~S} \\ & 563006 & 5 & \text { MDW } \\ & 566997 & 2 & \mathrm{H} \\ & 573024 & 39 & \text { MDW }\end{array}$


habitats which from their vegetation did not look acidic. Such local rarity in apparently suitable habitats was also noticed on Salisbury Plain by Cain and Currey $(1963 b)$. The majority of the plateau samples was taken from within gorse scrub, a habitat which Cain and Currey (1963a) suggest, for the Marlborough Downs, as being unusual for the species. In contrast to the rarity of $C$. nemoralis on the plateau, Helix aspersa Müll. and Theba cantiana Mont. were usually exceedingly common. It was apparent from records that $H$. aspersa was usually abundant where $C$. nemoralis was rare. Several localities off the chalk to the north of the central and eastern districts, and the valleys of the Ouse and Cuckmere, were searched for Cepaea, but it was not seen. Both $H$. aspersa and Th. cantiana were very abundant there.

The general distribution and abundance of $H$. aspersa on the South Downs contrasts with its status on downland in south-central England. There is a further feature of the land-snail fauna which is probably relevant to the present study on Cepaea. Cochlicella acuta Müll., like H. aspersa, has an atlantic distribution (Taylor, 1914; Boycott, 1934), but unlike it, it is maritime. Its typical habitat is duneland. Occurrence even 1 mile $(1 \cdot 6 \mathrm{~km}$.) inland is highly unusual (Dr G. Lewis, personal communication). The species was encountered on downland on four occasions in the region (tables $\mathrm{I}$ and 3 ; and at TQ 451.044$)$ between $2 \frac{1}{2}$ miles $\left(4.0 \mathrm{~km}\right.$.) and $3 \frac{1}{4}$ miles $(6.0 \mathrm{~km}$.) from the sea and up to 400 feet $(135 \mathrm{~m}$.) above sea-level. These records draw attention to certain subtle ecological differences between the South Downs and downland in south-central England.

C. hortensis was generally rare, and very local except in the eastern district (fig. 1, tables 1-4). In the western district it was found twice with $C$. nemoralis, once in dense scrub and once in long grass with some scrub; both colonies were at 500 feet $(165 \mathrm{~m}$.). Two unmixed colonies were found in dense scrub in the central district at 250 feet $(80 \mathrm{~m}$.). By contrast, the species was of relatively frequent occurrence in the eastern district, where ten colonies, seven of them unmixed, were found; nine were in scrub, and one in grassland, mostly above 500 feet. The relative abundance of records of this species from this district, which is the one with the most scrub, and its association with scrub in the other two districts, accord with Cain and Currey's findings that on high open downland $C$. hortensis is generally associated with bushes and trees.

\section{(ii) Morph frequencies in C. nemoralis}

I encountered the brown morph four times only (tables 1-3); in each case it occurred at low frequency. The four populations were living in habitats which were both brownish in background colour and sheltered.

Figs. 2 and 3 show the geographical distributions of the colour and banding morph frequencies respectively. The yellow morph predominates in populations in the western district. Populations near the 750-foot (250-m.) contour at Ditchling Beacon (TQ 331.130), the highest part of the region surveyed (fig. I), probably have the yellow allele $\left(C^{y}\right)$ at fixation, for six successive samples along the escarpment have no non-yellow morphs. The central district, particularly the eastern part, is characterised by populations with high frequencies of pink. Fig. 3 shows that populations on the whole have high or very high frequencies of the five-banded morph, especially on downland either side of the River Cuckmere, where many colonies are monomorphic for banding. Twenty-seven samples in a total east-west 
RICHARD W. ARNOLD

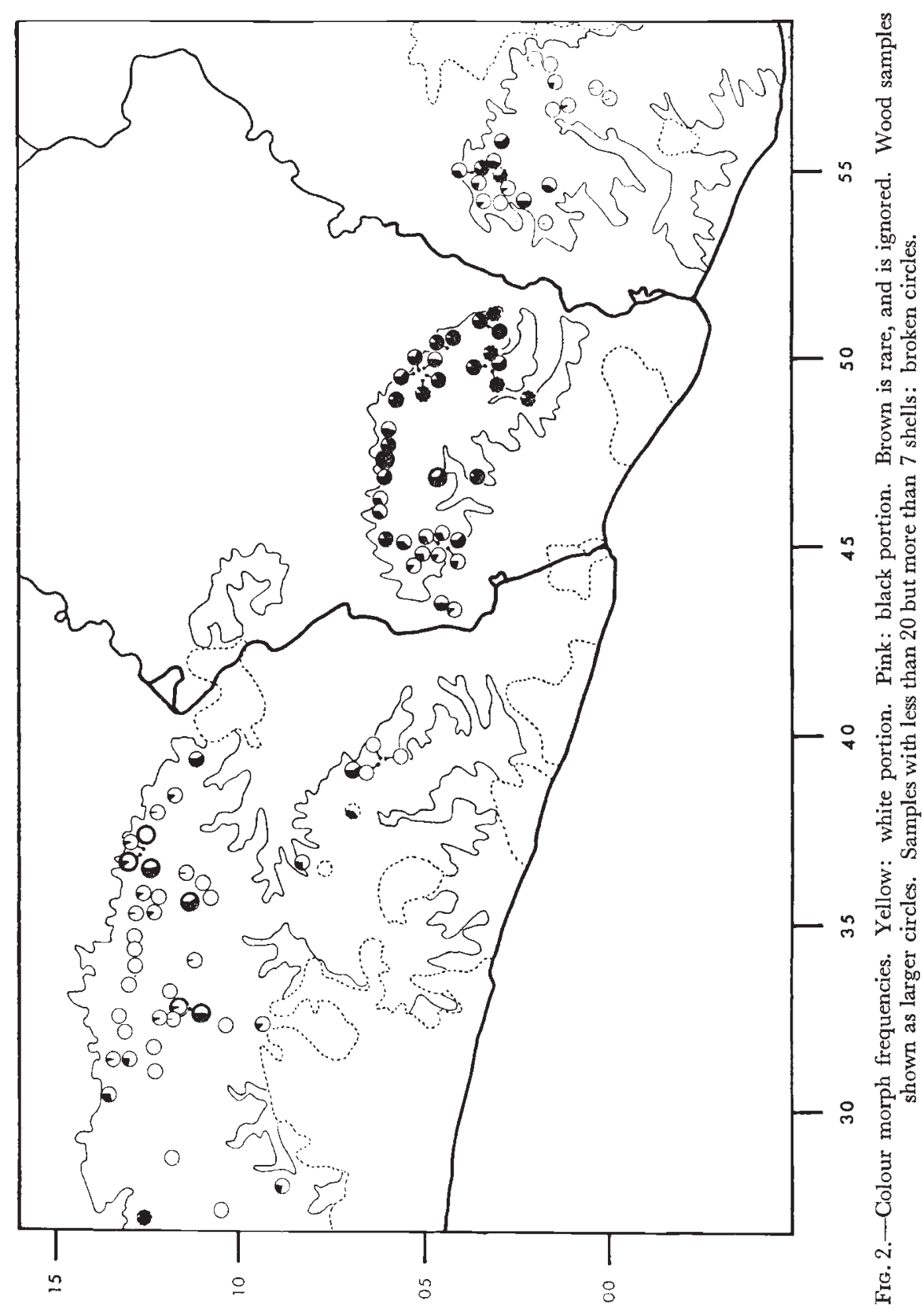




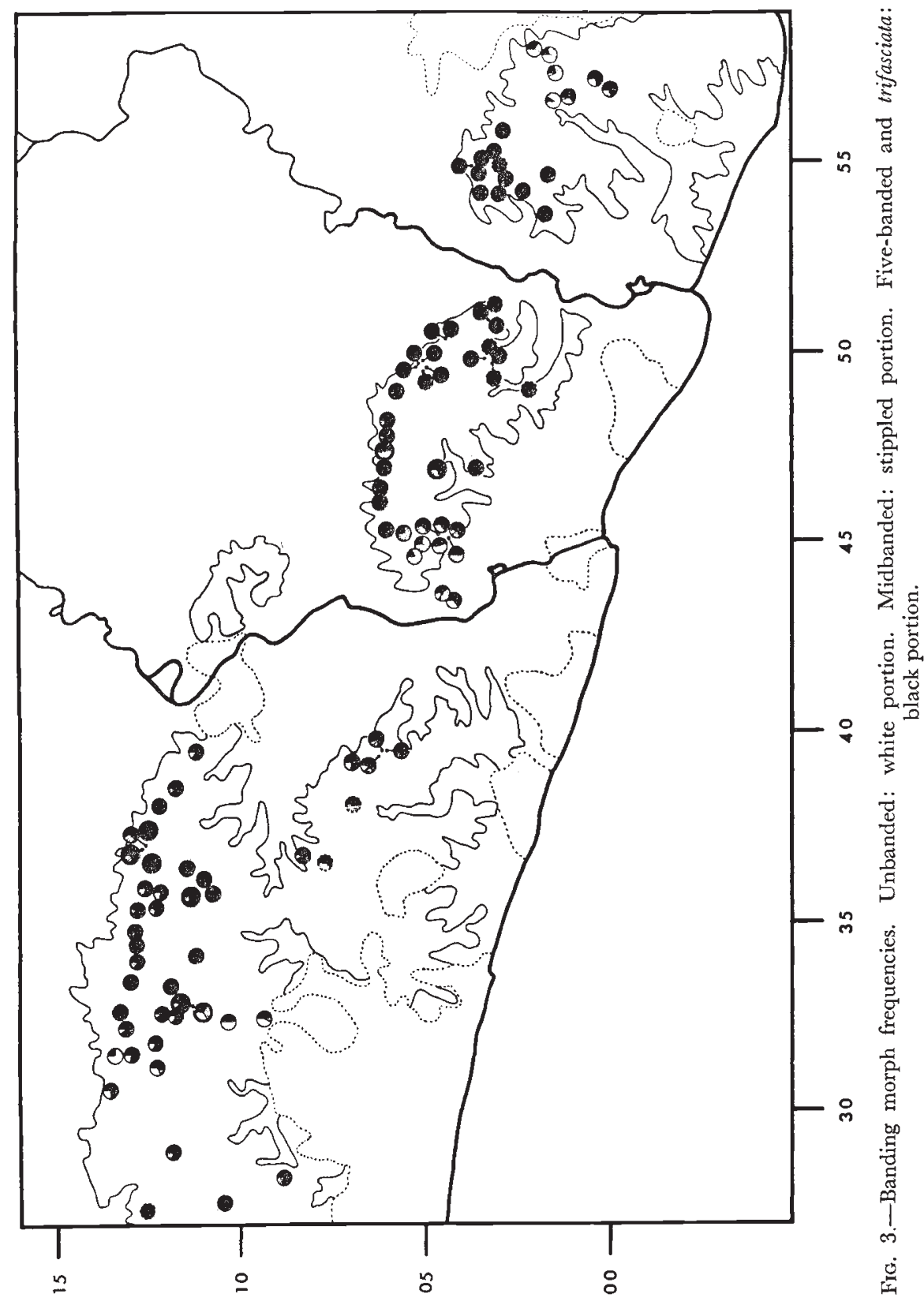


distance of 4 miles $(6.4 \mathrm{~km}$.) there have only three non-five-banded shells (in 1138 shells in the samples), each from a different colony. These three were trifasciata (formula 00345).

Unbanded is comparatively rare and local. Midbanded has only two centres of moderate to high frequencies, either side of the River Ouse, and in the east of the eastern district (fig. 3).

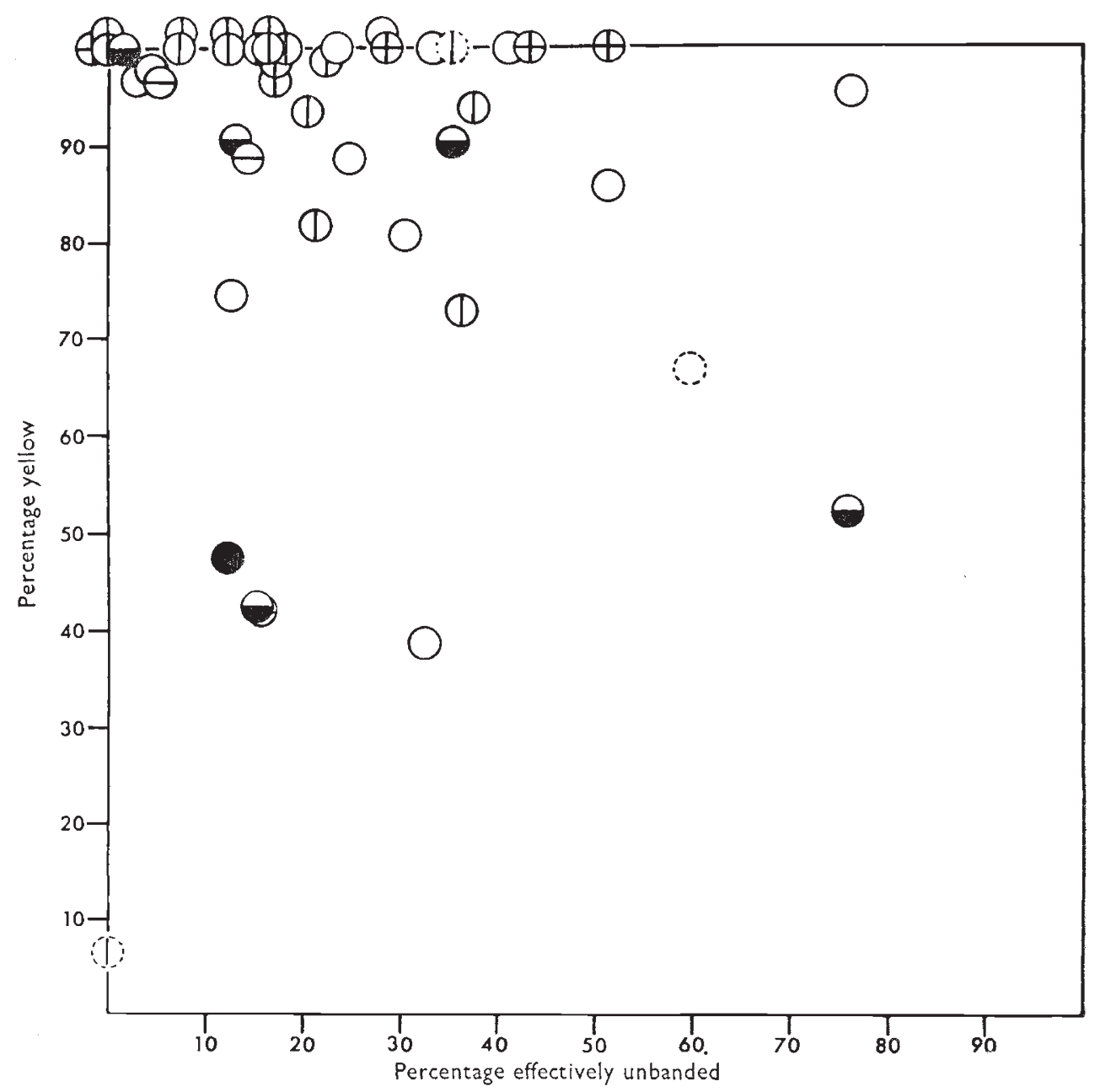

FIG. 4.-Scatter diagram for the western district. Grass: vertical line. Rough herbage: horizontal line. Hedgerow: cross. Scrub: open circle. Mixed deciduous wood: horizontal black. Beechwood: black. Small sample: broken circle.

Geographical areas of downland, therefore, are defined by different colour and banding morph frequencies, and there is a tendency towards reduction of the polymorphism of populations. Both are characteristics that are or tend to be shown by area effects. Consideration of morph frequencies in populations in relation to their backgrounds is contributory evidence that the morph frequency distributions found are area effects, and that physiological selection rather than visual selection plays the major role in determining the phenotypic composition of colonies on the Downs. 
Figs. 4, 5 and 6 are scatter diagrams displaying morph frequencies in colonies with respect to their backgrounds, following Cain and Sheppard (1954). The class effectively unbanded is comprised of all morphs which to a visual predator might appear unbanded $(00000,00300,00345$, and those with unpigmented, hyalozonate, bands). Area effects for yellow and for five-banded are confirmed for the western district (fig. 4), for none of the

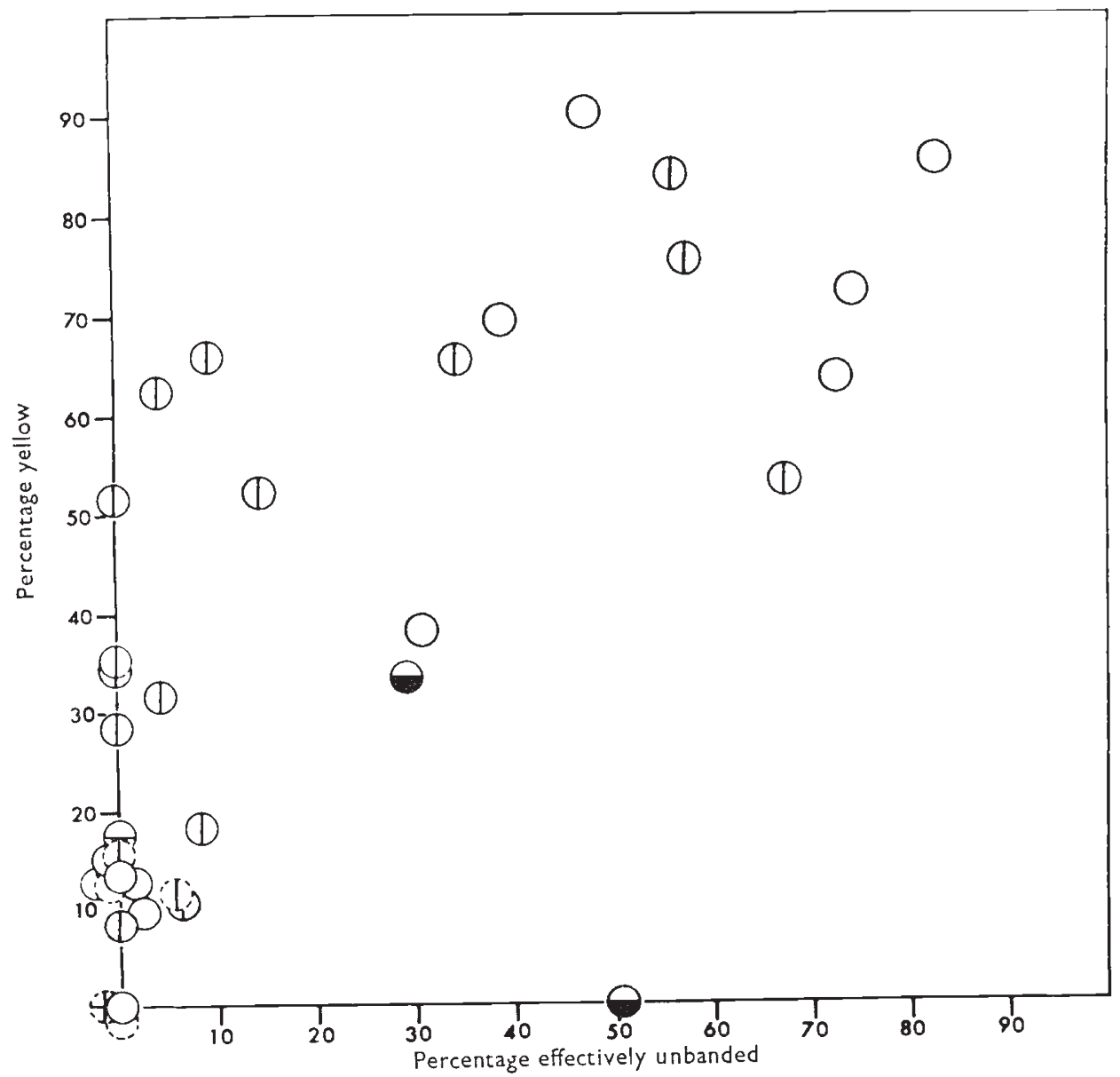

Frg. 5.-Scatter diagram for the central district. Symbols as fig. 4.

woodland samples agrees with the effective action of visual selection. Three are part of the family of open-habitat samples for both colour and banding frequencies, and the other three have rather high frequencies of yellow shells ( $>40$ per cent.) compared with populations in a region where visual selection is effective (e.g. near Oxford, Cain and Sheppard, 1954); five of the six have frequencies of effectively unbanded that are lower than expected with visual selection.

Samples from the central district do not match their backgrounds especially well for colour (although the majority of the pinks are pale), and the number of samples that are monomorphic for banding leads to the conclusion that there are area effects for pink and five-banded in this 
district. The area effect for five-banded extends across the River Cuckmere to encompass half of the eastern district as well (fig. 3).

The frequency of effectively unbanded morphs takes any value in populations in the western half of the eastern district (fig. 6) despite fixation of the gene for presence of bands $\left(B^{B}\right)$ and almost total absence of the major banding modifiers $\left(U^{3}\right.$, causing banded shells to be midbanded; and $T^{345}$,

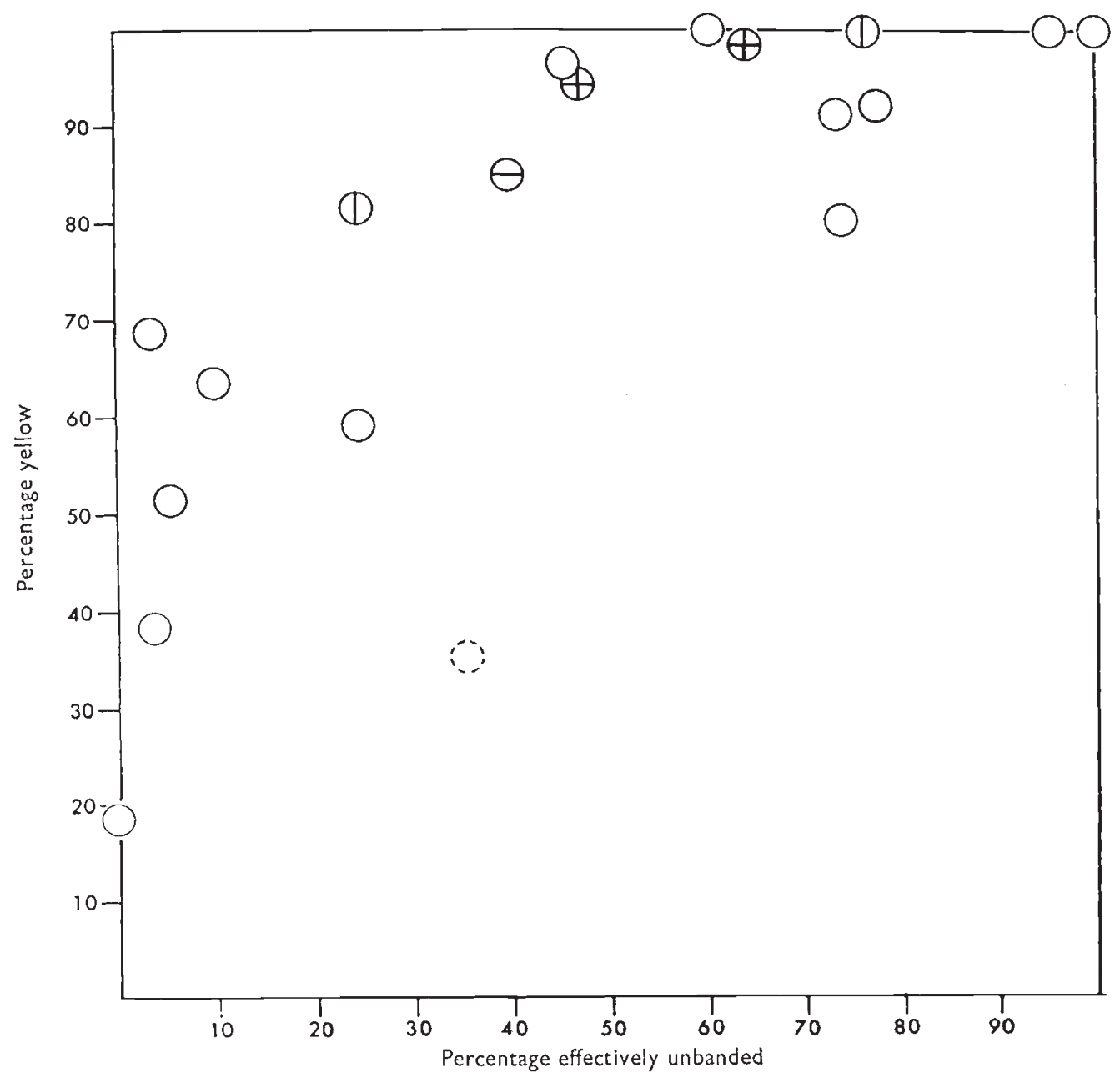

Fig. 6.-Scatter diagram for the eastern district. Symbols as fig. 4.

causing trifasciata). This is largely due to a high frequency of hyalozonate in some colonies. Hyalozonate is a condition in which the lip and bands are unpigmented (and a banded shell appears unbanded until closely examined). It is determined by a gene $\left(P^{T}\right)$ recessive to one of its commoner alleles $\left(P^{N}\right)$ causing normal pigmentation (Cain, King and Sheppard, 1960), and linked to the ground-colour $(C)$ and banding $(B)$ loci (Cook, 1967; Cain, Sheppard and King, 1968). Linkage is indicated in these data: of 831 yellows from the eastern district, 273 are hyalozonate whereas only one of the 173 pinks is hyalozonate. Few populations are polymorphic at this locus in Britain. 
The geographical distribution of hyalozonate is shown in fig. 7 (only one hyalozonate was found outside the eastern district). In the west of the eastern district, its area of occurrence coincides with the area of 100 per cent. five-banded; it extends eastwards into localities where unbanded and midbanded are present. Hyalozonate is present in all except four of the nineteen samples, three of which are at the eastern edge of the district.

The frequency of hyalozonate is unrelated to the visual characteristics of the backgrounds of the habitats (fig. 6). For example, it is 0 per cent. in one scrub habitat within its area of occurrence (and the frequency of the effectively unbanded class as a whole is 0 per cent. there), and it is 100 per cent. in another scrub habitat less than a mile away. Hence it can be concluded that an area effect for hyalozonate is present in this district.

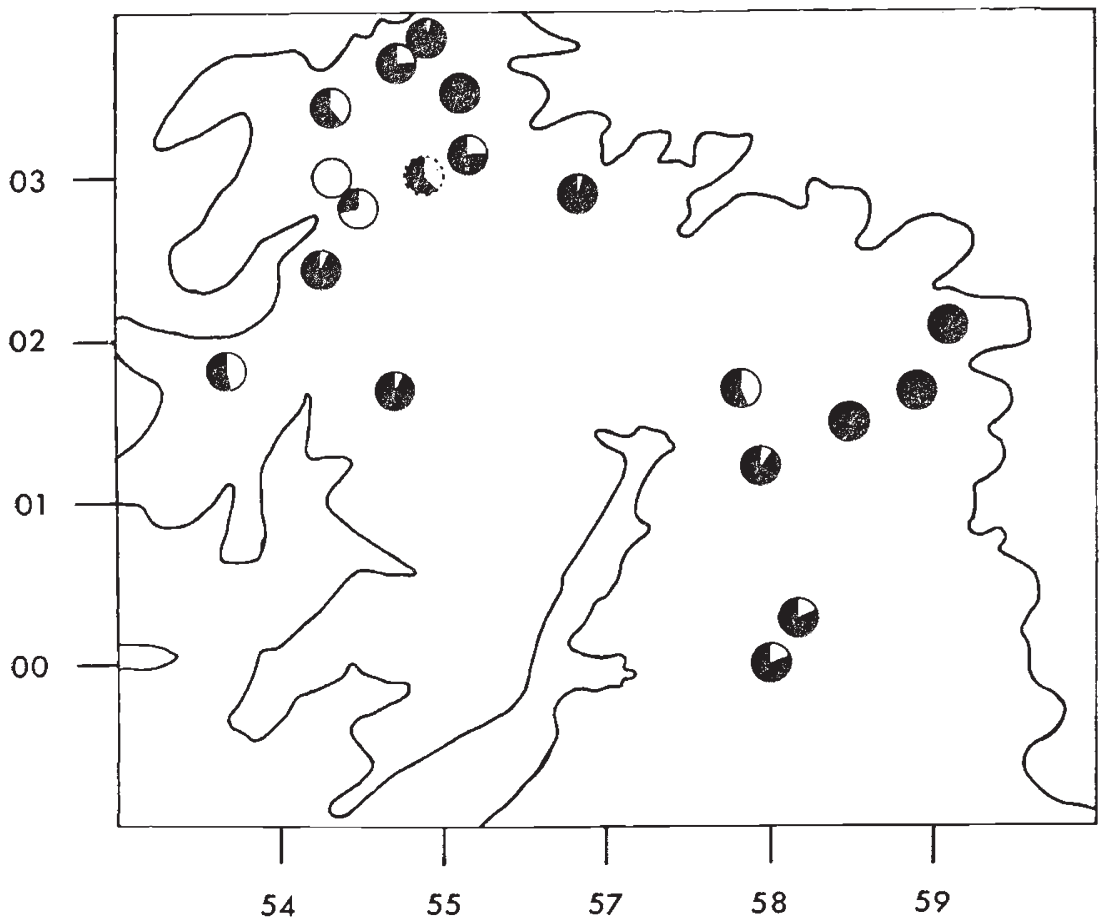

Fig. 7.-Distribution of hyalozonate morph frequencies (white portions of circles) in the eastern district. Contour at $500 \mathrm{feet}$. Grid interval $1 \mathrm{~km}$.

One of the colonies in the north-west may be monomorphic for it, as well as for other characters. The sample taken from this colony consisted of 110 dead adult shells, all of which were yellow, five-banded and hyalozonate (i.e. fixation of $C^{y}, B^{B}$ and $P^{T}$, as well as $U^{-}$and $T^{-}$). The colony was living in a fairly extensive gorse-brake which had been burnt. A search was made around the gorse-brake, but no further shells were found, and it appeared therefore that the colony was discrete and isolated. The nearest colony to it was discovered 250 yards away, also in a gorse-brake, on the other side of a re-entrant between the two colonies. The hyalozonate morph was also at high frequency in this colony ( 73.5 per cent.).

Some further evidence is available that visual selection has rather little effect on populations in the districts. As described above, scrub habitats 
(from which 40 samples with more than seven shells were taken) have darker backgrounds than grass habitats, and they are probably darker than hedgerows (seven) and rough herbages (five). Therefore it would be expected if visual selection were influencing morph frequencies in these open habitats that colonies living in scrub habitats would have a higher frequency of non-yellow morphs than colonies in the other types of open habitat. In no district was there any evidence for this (the sum of the chi-squareds for each district tested separately is $1 \cdot 70, \mathrm{P}>0.50$ ).

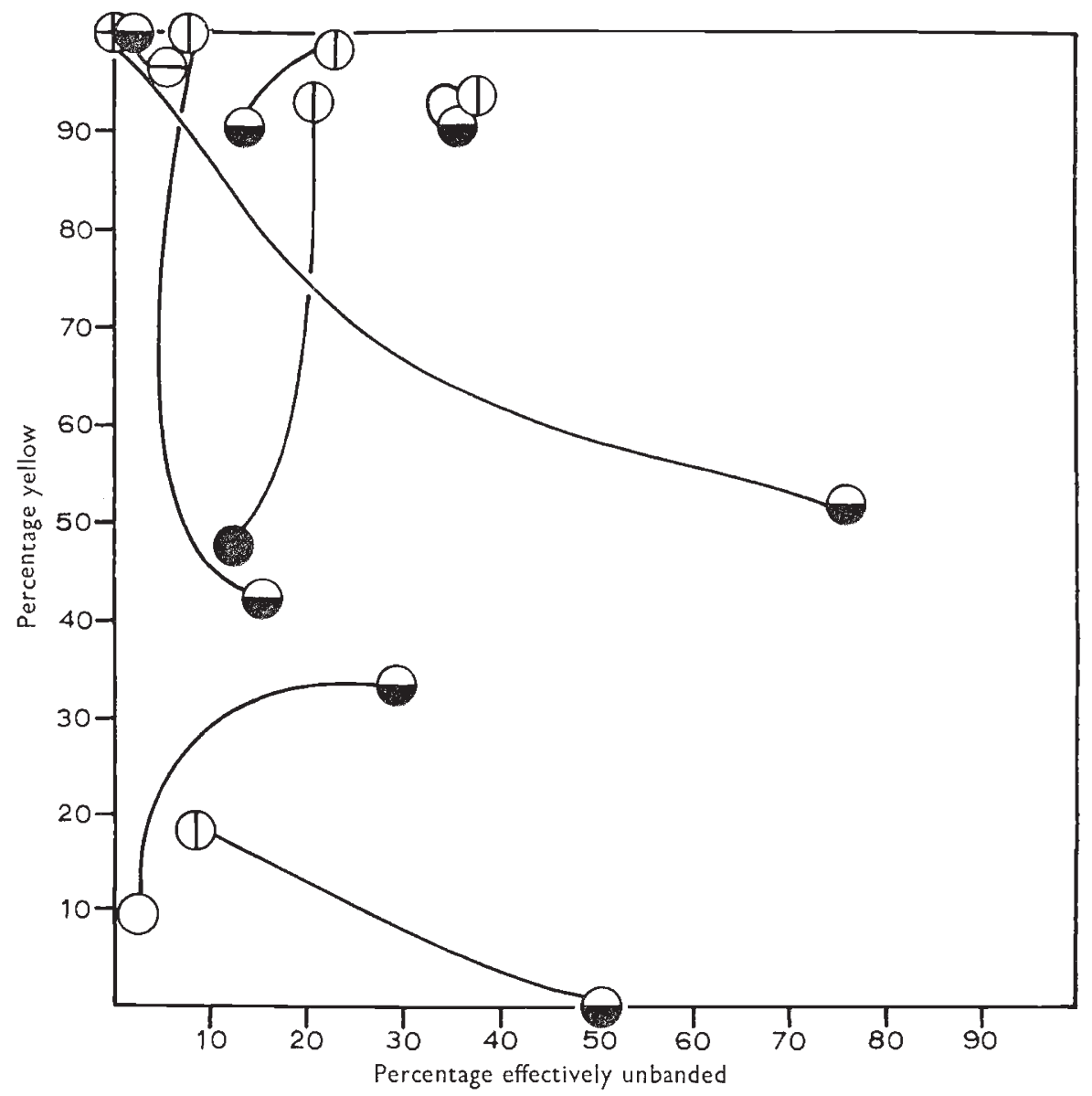

Fig. 8.-Paired wood and open-habitat samples from the east Sussex Downs. Symbols as fig. 4 .

\section{(ii) The influence of visual selection}

Although area effects are found in the region, there is nevertheless a small indication that visual selection may play some role in affecting morph frequencies, as Carter (1968a) demonstrated for colonies on the east Berkshire Downs. Figs. 2 and 3 show that when in an area there is a colony with exceptional colour or banding (or both) morph frequencies, that colony is often one living in woodland. Thus, the more northern of the two woodland populations in the central district is much more effectively unbanded than adjacent open-habitat ones (fig. 3). 
Evidence for the action of visual selection can be examined if each woodland example is compared with the nearest open-habitat sample, for morph frequencies in each member of a pair should be influenced in the same direction by the factors causing area effects. The method of pairing and analysis is described in Currey et al. (1964). The paired samples are shown in fig. 8, and the pairing is indicated in tables 1 and 2. Since three woods would be paired with one open habitat in one case and two with another if the nearest open habitat to each wood were always considered, I have assigned the nearest open habitats randomly to each wood, so that each wood is paired with a different open habitat. Only one open habitat, 75 yards from the wood (pair number (5), table 1), is within 100 yards of its paired wood; the greatest distance between members of a pair is 1200 yards.

Comparing each open habitat sample in turn with the woodland sample, the open habitat is:

$\begin{array}{lccc} & \text { Less yellow } & \text { More yellow } & \text { Totals } \\ \text { Less banded } & 1 & 3 & 4 \\ \text { More banded } & 1 & 3 & 4 \\ \text { Totals } & 2 & 6 & 8\end{array}$

The probability that two woodland samples do not agree with visual selection with respect to colour is 0.15 (one-tailed test). The number of woodland samples is small, and the result is not significant, but it is in the direction expected with visual selection. Further, whenever the frequency of colour or banding morphs in a woodland sample differs significantly from that of the open-habitat sample, it is always in the direction expected with visual selection. Thus, two differ significantly for both colour and banding (pair (7) in the central district, and pair (1) in the western district) and a further two differ significantly in the frequencies of the colour morphs (pairs (3) and (4) in the western district).

The evidence indicates that although factors producing area effects are of primary importance in affecting morph frequencies, there may be an interaction with visual selection in at least some localities on the eastern South Downs.

\section{Discussion}

The results from the South Downs are of interest in three respects. Firstly, a new kind of area effect, for the rare hyalozonate morph, is described, and one colony in the area appears to be monomorphic for it, as well as for other characters. Secondly, the Rivers Ouse and Cuckmere divide the eastern Downs into three districts such that populations between districts are almost certainly completely isolated from one another, and consideration of the extent of the area effects (with respect to barriers to gene flow) helps to provide evidence on their origin and nature. Thirdly, comparison may be effected between this region and other regions of chalk downland similarly surveyed for $C$. nemoralis populations in England.

\section{(i) The hyalozonate area, and the monomorphic colony}

Cain and Currey (1963a) argued that sampling drift is unlikely to be responsible for area effects on the Marlborough Downs and that selection is the most likely force causing and maintaining the morph frequencies in the areas. Nothing can be said about the forces causing the area effect for 
hyalozonate, except that the eastern district where it occurs is noticeably different from the other two districts (in which only one hyalozonate shell was found, in a colony in the western district), for it is the one which has the most cover from scrub. An area effect peculiar to it on the South Downs need not be considered surprising therefore, although what pertinent ecological aspects favour hyalozonate there compared with the other districts are unknown.

The complete reduction in the polymorphism and fixation of a rare allele in one of the colonies in the hyalozonate area might be due to drift or founder effect, but equally it could be due to selection. Two somewhat similar colonies were described by Cain and Currey (1963a) on the Marlborough Downs, and their arguments concerning them apply to the more extreme case described here. The monomorphic colony was found in an area effect for hyalozonate (and in part of a five-banded area) and nearby colonies exhibit high frequencies of the morph. The colony nearest to it, and apparently isolated from it, has the next highest frequency recorded in the area ( 73.5 per cent.). A local intensification of the forces causing the area effects at the locality could have been responsible for the further restricted variation of the monomorphic colony. Selection-here especially powerful for the yellow, five-banded, and hyalozonate phenotype-could hence explain the complete reduction in shell colour and banding variation exhibited by this colony. Founder effect cannot be dismissed. The distribution of hyalozonate frequencies in this district is indeed much as might be expected if there had been a founding hyalozonate population, with dispersal from it of a competitively superior genotype into previously nonhyalozonate populations. Experiment might be possible in the monomorphic colony (of which further study is required) to test the two possibilities. If, after estimation of the population size, individuals bearing dominant alleles at some or all loci were introduced from colonies in the vicinity, an increase in the frequency of these alleles could indicate that founder effect had been responsible for the colony. A decrease in frequency would mean little: merely perhaps that the introduced genes were at a selective disadvantage against the genetic background of the endemic snails.

\section{(ii) Barriers and the nature of area effects}

There are two theories concerning the nature of area effects. Cain and Currey $(1963 a, c)$ concluded that differential environmental selection between areas primarily caused the different banding and colour morph frequencies in them. Goodhart (1963) on the other hand proposed that area effects were caused in the past by different founder populations colonising chalk downs carrying or developing different co-adaptations. Spreading from the founder populations into hitherto uncolonised land led to the area effects observed at the present day. Gene frequencies would on this idea be determined largely irrespective of the external environment.

As Carter (1968a) has argued, if an area effect is found on both sides of a barrier to gene flow, it is improbable that that area effect was caused in the way Goodhart suggested. It is unlikely that land on both sides of a barrier to gene flow, such as a river, would have been originally colonised by similar founding populations, particularly as Goodhart's hypothesis requires that non-isolated areas of downland would have had to have been colonised by different ones. 
CEPAEA NEMORALIS ON THE EAST SUSSEX SOUTH DOWNS 293

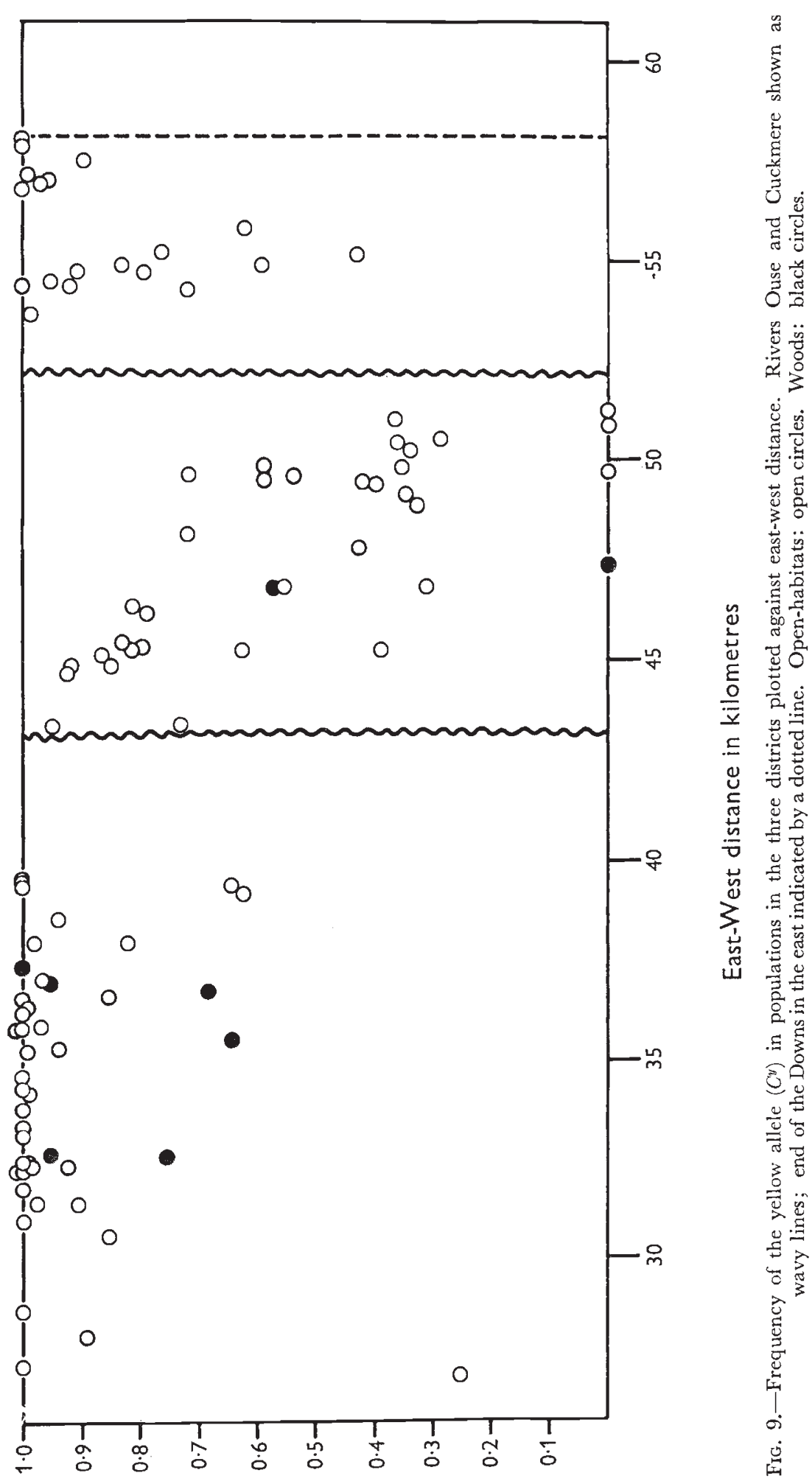


Further evidence on the point is especially desirable, particularly in view of Goodhart's interpretation of the nature of area effects, and the relevance of such ideas to what Cain (1954) gave the name semi-sympatric speciation. These ideas have been reviewed by Clarke (1968) with particular respect to geographical differentiation in Partula and Cepaea.

The east Sussex South Downs are well suited topographically for testing whether similar area effects may be found on both sides of a barrier, for the Rivers Ouse and Cuckmere probably completely isolate populations in the
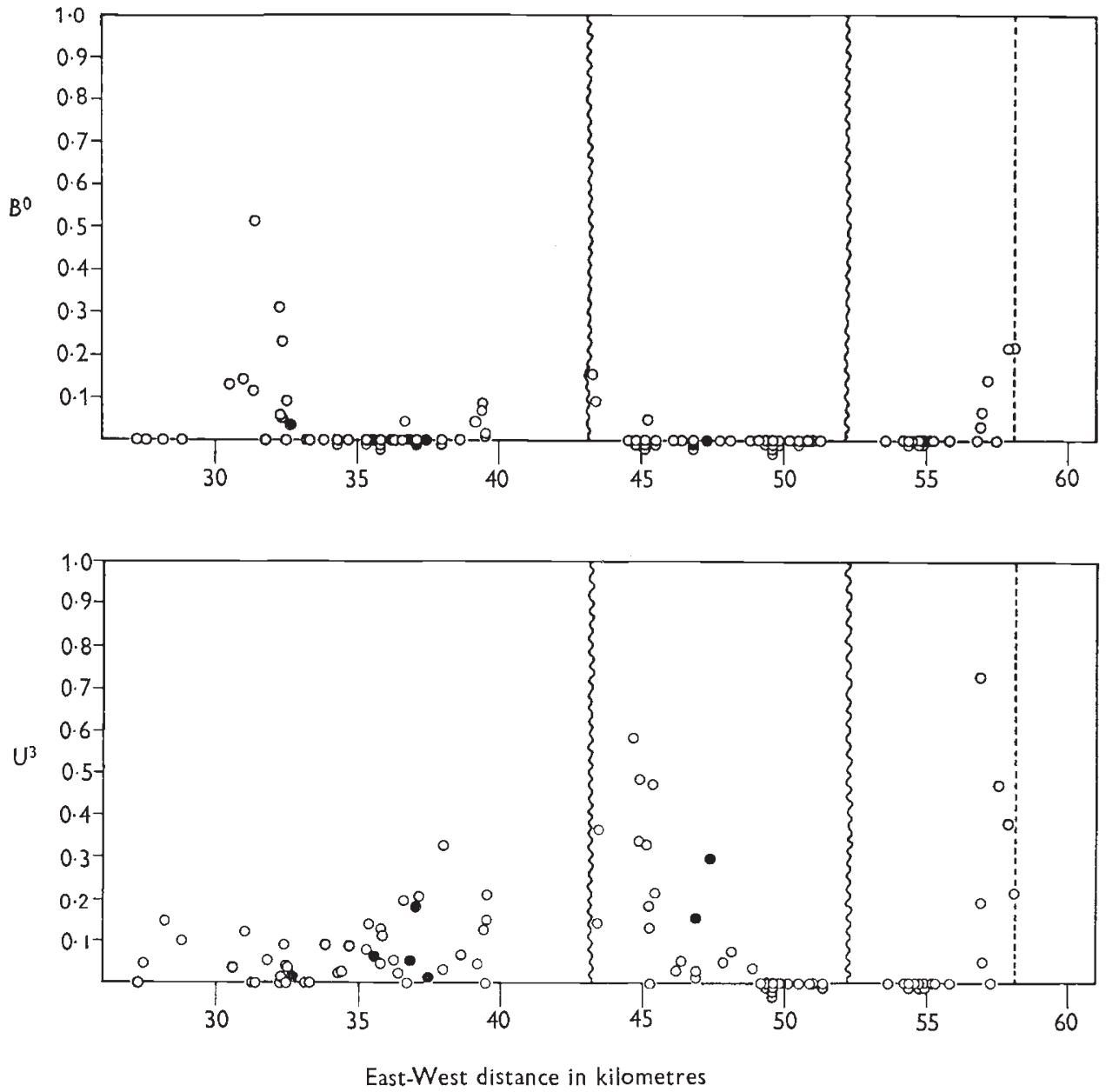

FIG. 10.-Frequencies of the unbanded $\left(B^{O}\right)$ and midbanded $\left(U^{3}\right)$ alleles in populations in the three districts plotted against east-west distance. Symbols as fig. 9 .

three districts. The rivers are several yards wide as they flow between the downland districts, and both have flood plains of about $\frac{1}{2}$ mile $(1 \mathrm{~km}$.) width at their narrowest in which Cepaea appears to be absent.

Figs. 9 and 10 show the frequencies of $C^{y}, U^{3}$, and $B^{\circ}$, calculated on the assumption that Hardy-Weinberg conditions obtain, plotted against longitude. Populations either side of the River Ouse tend to have intermediate frequencies of $C^{y}$ (with three exceptions, located close to one another) as 
part of a cline running from the centre of high frequency of pink in the central district to that of high frequency of yellow in the western district. The same is not true, however, of colonies either side of the River Cuckmere (fig. 9). For $U^{3}$ and $B^{O}$ the agreement on each side of the barriers in each case is good. Both genes are absent either side of the River Cuckmere, such that fifteen colonies on the west are similar to twelve on the east for banding (populations are practically monomorphic for five-banded). Further, $U^{3}$ has one of its few centres of high frequency on downland either side of the River Ouse (fig. 10). $B^{O}$ is present on seven colonies near the River Ouse, four on one side and three on the other; otherwise it is absent (with the exception of one colony) in populations for several miles to the east and west of the river. In five instances out of six, therefore, similar gene frequencies are exhibited by populations on either side of the barriers, and it can be said with some confidence that the area effects for colour and banding on these downs are unaffected by the geographical barriers of rivers and their flood plains.

The evidence supports Carter's findings. It may be concluded that it is more probable (the evidence being only circumstantial) that similar environmental forces are responsible for the same area effect on both sides of a barrier; and that environmental selective forces, and not random events in the past followed by co-adaptation - a theory for which there is no evidence - are likely to be responsible for area effects.

(iii) Comparison with the area effects on other chalk downs, and evidence for the selection causing the South Downs area effects

The present paper gives the results of the fifth survey of populations on chalk downs which have been described. Area effects as extensive as those found elsewhere occur, and a comparison may usefully be made. There is one main feature in which the area effects described here contrast with those found in south-central England: $U^{3}$ seldom reaches high frequencies. In south-central England, $U^{3}$ is usually the cause of some marked area effects in all regions surveyed on chalk downs (Cain and Currey, 1963a, $b$; Carter, 1968a). There is a similarity in this respect, on the other hand, between the present survey and populations on the Purbeck Hills in Dorset, the other downland system described for the south coast. The main area effects there are for five-banded (Carter, 1968a), although $U^{3}$ does sometimes reach high frequencies in populations in the east of the region sampled.

Climatic selection may be very difficult to identify (especially where climatic differences between the localities and regions of interest are small) for it may be necessary to know when selection due to climate is most effective during the life history of species: overall mean climatic data may be largely uniformative. Further, climate may well act through intermediary selective agents. Nevertheless, climatic selection is the first and most obvious environmental agent to consider when attempting to understand area effects.

Compared with south-central England, the south coast receives slightly higher rainfall, it has higher winter temperatures, and it receives more sunshine. Thus, compared with Oxford, Brighton receives 5.8 inches ( $147 \mathrm{~mm}$.) more rain per year, its mean monthly temperature is consistently $1^{\circ} \mathrm{F}$. $\left(0.6^{\circ}\right.$ G. $)$ higher between September and February, and it receives nearly 300 more hours of sunshine yearly (Atlas of Britain, 1963). The humidity 
of the air is greater, and there are many species of Angiosperms (for example, Pennywort, Umbilicus rupestris Salisb.) which flourish in the west of the British Isles and along the south coast as far as Kent (Perring and Walters, 1962), probably in many cases a consequence of warmer and more humid conditions there. Indeed, for the South Downs there is evidence from the abundance of Helix aspersa and from the unusual presence inland of Cochlicella acuta that their maritime climatic attributes (rather than their continental ones, like high sunshine hours) are important in the ecology of the land-snails found on them. It may tentatively be suggested then that it is such conditions which favour five-banded on chalk. It is perhaps relevant here that Lamotte (1954) found five-banded most common in the north of France, in the departments of Nord and Pas-de-Calais (as well as in mountainous regions); the region is calcareous and near the sea.

With respect to the colour morphs, there are two regularities to which attention can be drawn. Firstly, brown is rare, much rarer than on other chalk downs described for Cepaea. This agrees with current ideas on the action of selection on the colour morphs, that brown is rarer in warmer and more southern regions (Cain and Sheppard, 1954; Lamotte, 1959; Cain and Currey, 1963a; Cain, 1968; Carter, 1968a; Arnold, 1970). Secondly, the South Downs have the only strong area effect for pink described on chalk downs, and this agrees with present ideas of climatic selection-that it is, like five-banded, a morph which is favoured in mild conditions. The presence of a strong area effect for pink on the South Downs is therefore unsurprising if it is their maritime climatic attributes which are important. Further, it is in the highest parts of the South Downs, around 750 feet (250 m.) that yellow is most frequent. Carter (1968a) drew attention to very high frequencies of yellow on the highest parts of the Berkshire Downs also. This suggests that yellow is favoured in the most exposed conditions on chalk in England. This agrees with evidence that yellow is favoured in more extreme climatic conditions.

Suggestions about the general effect of climate in producing area effects are mainly made possible by work in climates extreme for the species, and by experimental evidence. Firstly, it is known that area effects for fivebanded and (to a lesser extent) for pink occur at intermediate altitudes in the Pyrenees, indicating that these morphs are favoured in milder climatic conditions (Arnold, 1968, 1969). Secondly, experiments on resistance to extremes of temperature show that both five-banded and pink are less resistant than the other banding morphs and yellow (Lamotte, 1959, 1966). Guerrucci-Henrion (1966), working in Brittany, found a positive correlation between the frequency of pink in populations and rainfall, providing further evidence that pink is favoured in more humid conditions, but she found no correlation between the frequencies of the banding phenotypes and rainfall.

The selective factors causing different area effects on chalk in England are as yet unsubstantiated, but the evidence enables the hypothesis to be advanced that area effects in five-banded, and pink, are to be expected more frequently in milder climatic conditions on chalk, as Cain (1968) has suggested from a consideration of sand-dune populations of $C$. nemoralis.

The idea demands that it is not the comparative environmental severity of chalk downland which causes area effects, and the consequent overriding of visual selection, for then it would be difficult to see how area effects in those morphs favoured or less disadvantageous in milder climatic regimes 
could occur, but rather than a relative weakness of visual selection permits area effects to occur. There is evidence that visual selection is weaker on downland than in lowland wooded country.

(1) An important visual predator of Cepaea, the Song Thrush, which exerts strong visual selection (Sheppard, 1951; Arnold, 1966; Carter, $1968 b$ ), and which experiments show is probably by far the most important predator of adult Cepaea at least in some habitats (Arnold, unpublished) is essentially a woodland species (Witherby et al., 1943). Experiments show that it predates snails very much more in woodland than in nearby grassland (Arnold, 1970). Downland is grassland by definition.

(2) Observations and experiments show that this predator eats snails more regularly year-to-year in wooded districts rather than on open downland (Arnold, 1966; Cain and Currey, 1968).

(3) Populations on the wooded Chiltern Hills, as high as the Marlborough Downs where strong area effects occur, vary with habitat (Arnold, 1966). The most likely explanation is that Song Thrushes are common on the Chilterns, and rare on the open downs. High chalk itself does not mean that area effects will be found there.

It can be suggested, therefore, that the strength of visual selection is likely to be considerably reduced in places where area effects are found. If climate is acting to cause regularities in the broad geographical distribution of area effects in particular morphs, area effects in those morphs which evidence indicates are found more frequently in milder climates need not be considered surprising.

\section{Summary}

1. Visual selection generally has little influence on the phenotypic composition of populations of Cepaea nemoralis on the eastern South Downs. The most striking area effects are for the five-banded, pink, and hyalozonate morphs.

2. Several of the area effects are the same on both sides of barriers to gene flow, suggesting that similar environmental forces either side of the barriers are responsible for them. This is evidence (additional to Carter's, 1968) against the theory that the area effects so far described are due to founder effect and co-adaptation.

3. Midbanded, usually showing strong area effects on downland in south-central England, seldom reaches high frequency. Area effects in banding are mainly for five-banded.

4. It is suggested that the maritime component of the climate of the South Downs is important in causing area effects in five-banded, and in pink.

5. This is consistent with evidence on climatic selection. It is likely that area effects for the five-banded and pink morphs may be found more frequently on downland where the climate is milder.

6. Reduced visual selection on downland probably allows other selective forces like climatic ones largely to determine morph frequencies there.

Acknowledgments.-I am very grateful to Professor A. J. Cain, my supervisor when this work was done, for his advice and for his criticism of this paper; to Dr E. R. Creed, for criticism of the paper; to Dr M. A. Carter, for valuable discussion, and to him and to Dr P. P. Feeny for their generous assistance in the collecting of samples. Various farmers kindly allowed me to camp on their land. I wish to thank Professor J. W. S. Pringle for the facilities available in his department, and the States of Guernsey for financial support. 


\section{References}

ARNOLD, R. W. 1966. Factors affecting gene-frequencies in British and continental populations of Cepaea. Doctoral thesis, Bodleian library, Oxford.

ARNold, R. W. 1968. Climatic selection in Cepaea nemoralis (L.) in the Pyrenees. Phil. Trans. Roy. Soc. Lond., B, 253, 549-593.

ARNOLD, R. W. 1969. The effects of selection by climate on the land-snail Cepaea nemoralis (L.). Evolution, 23, 370-378.

ARNOLD, R. W. 1970. A comparison of populations of the polymorphic land-snail Cepaea nemoralis (L.) living in a lowland district in France with those in a similar district in England. Genetics, 64, 589-604.

ATLAS OF BRITAIN AND NORThERN IRELAND. 1963. Clarendon Press, Oxford.

BOyсот, A. E. 1934. The habitats of land Mollusca in Britain. J. Ecol., 22, 1-38.

CAIN, A. J. 1954. Animal Species and their Evolution. Hutchinson, London.

CAIN, A. J. 1968. Sand-dune populations of Cepaea nemoralis (L.). Phil. Trans. Roy. Soc. Lond., B, 253, 499-517.

CAin, A. J., AND currey, J. D. 1963a. Area effects in Cepaea. Phil. Trans. Roy. Soc. Lond., B, $246,1-81$.

CAIN, A. J., AND CuRRey, J. D. 1963b. Area effects in Cepaea on the Larkhill Artillery Ranges, Salisbury Plain. F. Linn. Soc. Zool., 45, 1-15.

CaIn, A. J., AND currey, J. D. 1963c. The causes of area effects. Heredity, 18, 467-471.

CAIN, A. J., AND CURREY, J. D. 1968. Ecogenetics of a population of Cepaea nemoralis (L.) subject to strong area effects. Phil. Trans. Roy. Soc. Lond., B, 253, 447-482.

CAIN, A. J., KING, J. M. B., AND SHEPPARD, P. M. 1960. New data on the genetics of polymorphism in the snail Cepaea nemoralis (L.). Genetics, 45, 393-411.

CAIN, A. J., AND SHEPPARD, P. M. 1950. Selection in the polymorphic land snail Cepaea nemoralis. Heredity, 4, 275-294.

CAIN, A. J., AND ShEPPARD, P. м. 1954. Natural selection in Cepaea. Genetics, 39, 89-116.

CAIN, A. J., SHEPPARD, P. M., AND KING, J. M. B. 1968. The genetics of some morphs and varieties of Cepaea nemoralis (L.). Phil. Trans. Roy. Soc. Lond., B, 253, 383-396.

GARTER, M. A. 1968a. Area effects and visual selection in Cepaea nemoralis (L.) and Cepaea hortensis (Müll.). Phil. Trans. Roy. Soc. Lond., B, 253, 397-446.

CARTER, M. A. $1968 b$. Thrush predation of an experimental population of the snail Cepaea nemoralis (L.). Proc. Linn. Soc. Lond., 179, 241-249.

CLARKE, B. C. 1968. Balanced polymorphism and regional differentiation in land snails. In Evolution and Environment, edited by E. T. Drake. Yale University Press, New Haven.

COOK, L. м. 1967. The genetics of Cepaea nemoralis. Heredity, 22, 397-410.

GURREY, J. D., ARNOLD, R. W., AND CARTER, M. A. 1964. Further examples of variation of populations of Cepaea nemoralis with habitat. Evolution, 18, 111-117.

GOODHART, C. B. 1963. "Area effects" and non-adaptive variation between populations of Cepaea (mollusca). Heredity, 18, 459-465.

GUERRUCGI-HENRION, M. A. 1966. Recherches sur les populations naturelles de Cepaea nemoralis en Bretagne. Arch. Zool. Exp. E̊ Gén., 107, 369-417.

цамотте, м. 1954. Distribution en France des divers systèmes de bandes chez Cepaea nemoralis. F. de Conchyl., 94, 125-147.

LAмотте, м. 1959. Polymorphism of natural populations of Cepaea nemoralis. Cold Spring Harbor Symp. Quant. Biol., 24, 65-84.

LAMOTTE, м. 1966. Les facteurs de la diversité du polymorphisme dans les populations naturelles de Cepaea nemoralis (L.). Lavori della Società Malacologica Italiana, 3, 33-73.

PERring, F. m., AND WAlters, s. m. 1962. Atlas of the British Flora. Nelson, London.

SHEPPARD, P. M. 1951. Fluctuations in the selective value of certain phenotypes in the polymorphic land snail Cepaea nemoralis. Heredity, 5, 125-134.

TAYLOR, J. 1914. Monograph of the Land and Freshwater Mollusca of the British Isles, Taylor, Leeds.

WITHERBY, H. F., JOURdAIN, F. c. R., TICEHURST, N. F., AND TUCKER, B. w. 1943. The Handbook of British Birds. H. F. \& G. Witherby, London. 